\title{
An eyewitness account of the Bhuj earthquake
}

\author{
M K Gupta \\ India Meteorological Department, Pune 411 005, India.
}

The occurrence of a severe earthquake is a rare event with its effect localized in a limited region. There are no prior indications of its occurrence too; hence experiencing such an event is just a matter of chance, which the author had by virtue of his posting at Bhuj. This paper presents a detailed account of observations made in the wake of the Bhuj earthquake of January 26th 2001, describing physical and mental reactions during the earthquake, the post-quake scenario, the nature and cause of damage to buildings, the trend of aftershocks, various deformities, including ruptures and fissures on the surface of the earth, etc. which may be useful for a detailed study of the seismological activity in the region.

\section{Introduction}

Most earthquakes in the world occur at plate boundaries and only a few are found in the interior of continents. India is also unusual for a large number of damaging earthquakes that occurred within the Indian plate. Kutch is one such midplate region, which extends approximately $250 \mathrm{~km}$ $(\mathrm{E}-\mathrm{W})$ and $150 \mathrm{~km}(\mathrm{~N}-\mathrm{S})$ and is bounded by Nagar Parkar Fault in the north and the Kathiawar Fault in the south as shown in figure 1 (taken from Malik et al 1999). The portion bounded between these two faults is further marked by several major faults viz., Katrol Hill Fault, Kutch Main Land Fault, Banni Fault, Island Belt Fault and Allah Bund Fault. The Kutch peninsula has experienced several incidents of earthquake along these faults (Malik et al 1999). Some of the major earthquakes known to have occurred in the region are on 6-51668 (ML-7.6), 16-6-1819 (ML-8), 19-6-1845 (ML6.3) and 21-7-1956 (ML-7). Kutch is, therefore, classified as a seismically active zone-V (Bureau of Indian Standards IS-1893:1984). The Bhuj earthquake of January 26th, 2001 is the most recent and the most disastrous mid-plate event.

\section{Detailed account of Bhuj earthquake}

The occurrence of weak but frequent tremors with epicenters around Bhavnagar from August 2000 to December 2000 had led to a shift in focus from the most seismologically sensitive zone of Kutch (zone $\mathrm{V})$ to a two-level lesser sensitive zone around Bhavnagar (zone III). The adjoining Kutch region, classified as seismic zone $\mathrm{V}$ - a very high damage risk zone, had experienced no seismic activity for nearly four years since February 1996 except a tremor of magnitude 4.5 which had occurred on December 24th, 2000 with its epicenter located $70 \mathrm{~km}$ $\mathrm{NE}$ of Bhuj. The tremor was hardly felt in the region.

In the absence of any forecasting technique, the state administration and the scientific community could not anticipate the approaching disaster of January 26th, 2001. The hypo central parameters of Bhuj earthquake are as below:

- Origin time: 08:46:42.9 hrs IST.

- Epicentre: $23.4^{\circ} \mathrm{N}, 70.3^{\circ} \mathrm{E}$.

- Focal depth: $25 \mathrm{~km}$.

- Magnitude (Richter scale): 6.9.

Keywords. Bhuj earthquake; Kutch; physical feeling; aftershocks. 


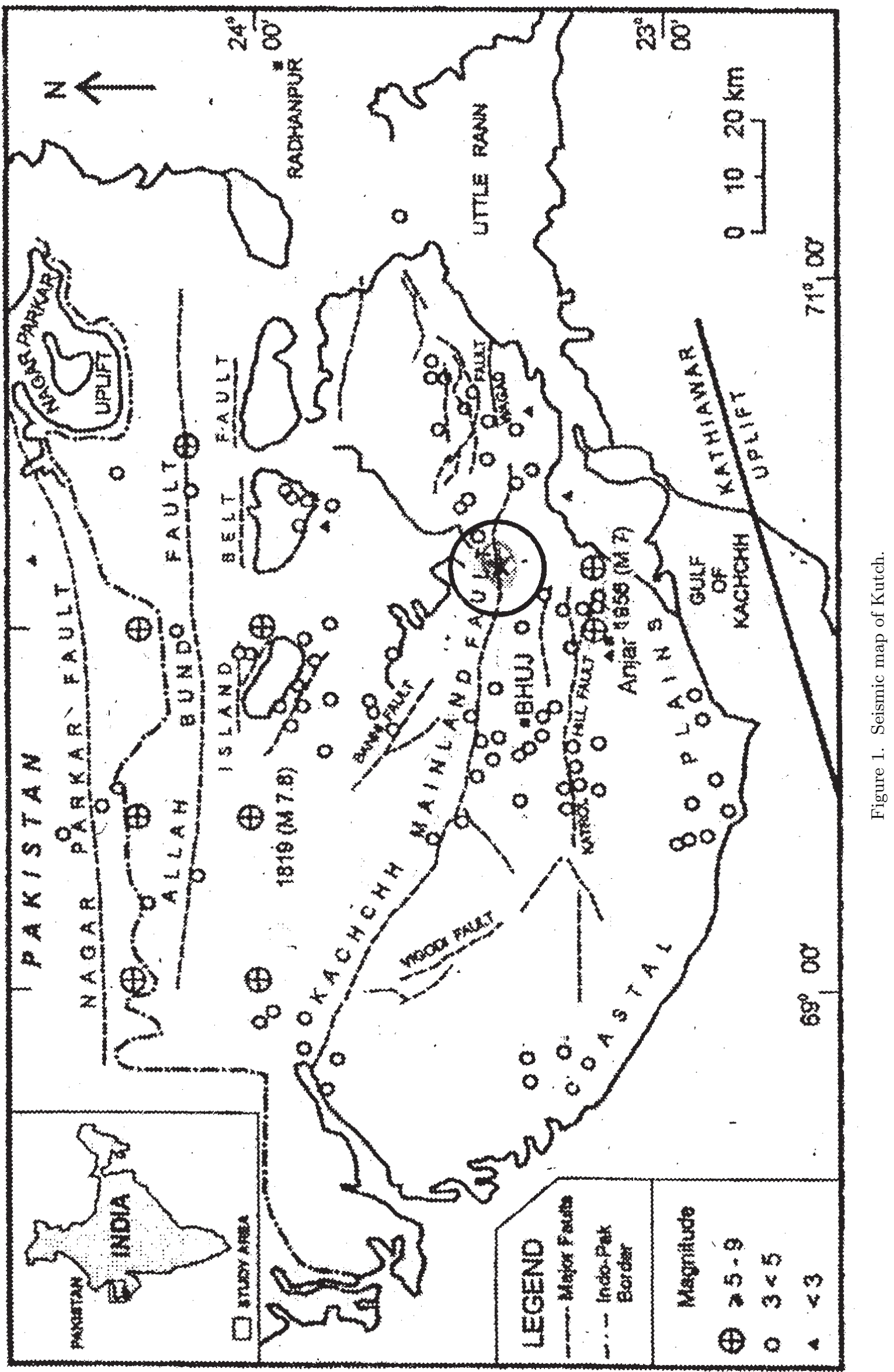




\subsection{Physical and mental experience during the earthquake}

The tremor on January 26th, 2001 started at $8.46 \mathrm{am}$. The initial displacement of the ground was felt in a northerly direction with a sound resembling to that of heavy furniture being pulled over a rough surface. The tremor was felt physically for about a 100 seconds and recorded by Digital Broadband Seismograph of India Meteorological Department for about 500 seconds (figure 2). During the 100 seconds period the intensity of the tremor and the accompanying rumbling noise gradually diminished and suddenly increased at least three times. More jerks were felt in a N-S direction than in a E-W direction. The plinth of the nearest building was observed to be oscillating through a distance of about $20 \mathrm{~cm}$. This is evident from the fact that almost all items in cupboards along the E-W wall fell down while those in cupboards along the N-S wall were found less affected. In addition, the author felt a high-frequency vibration through his feet which could mean that a fissure might be developing just below the feet.

\subsection{Post-quake scenario}

A deathly silence was felt just after the tremor stopped. Dust rose in the atmosphere reducing the visibility to less than $1 \mathrm{~km}$. All the lanes in the central part of Bhuj were full of rubble and debris at an average one metre high. There was no access to houses in that area except to climb and walk over the debris. The complete infrastructure of the region like electric power, water supply, medical facility, telecommunication, rail and road transport, etc. was disrupted. The earth felt as if it was floating for the next few days. Landing and take off sounds of the aeroplanes from the airport $8 \mathrm{~km}$ away severely echoed through the entire Bhuj town for the next one month.

The people of the region suffered various difficulties. The first two nights were horrible. Complete darkness, cold weather and frequent tremors did not allow the people to sleep. There was no water supply for the next four days. The suffering of those who lost their shelters is indescribable. Because of wide spread damage and disruption of rail and road links, it took a considerable time for relief to reach the region.

\subsection{Nature and cause of damage to buildings}

Old and poorly-built buildings completely collapsed in Bhuj, Bhachau, Anjar, Gandhidham and Rapar towns and in several villages of Kutch district. The maximum percentage of damage was in and around Bhachau followed by Anjar, Gandhidham, Bhuj and Rapar.

Almost all multistoreyed buildings (4 or more floors) suffered heavy damage. They were thrown out of plumb and their panel walls thrown out of their frame structure. Some of them completely collapsed. In some cases, one or two of the lowest floors plunged into the ground. More damage was observed in the newly built, 2-3 years old, multistoried buildings as compared to the $5-10$ years old ones. More damage was observed in the ground floor structure as compared to the upper floors.

Constructions which were heavier on top rather than their base and those which were supported on one side like balconies extruding out of buildings, and even staircases, could not bear the shock and broke down.

Well-built one or two storied buildings suffered only minor damages with mainly cracks in the plaster.

\section{Trend of aftershock}

There were frequent tremors of magnitude up to 5.0 on the Richter scale for about a month and up to a magnitude of 3.0 still continue. For the first week people did not dare enter the damaged buildings and the walled Bhuj city except to save lives or to retrieve dead bodies. People were forced to save and retrieve their property even after one week as there was no significant reduction in the frequency of aftershocks.

The frequency of tremors was so quick for the following one month that the digital broadband seismological recorder could only enable us to count the tremors otherwise traces on the analog chart severely overlapped rendering it difficult to analyse them. Tremors of magnitude more than 3.0 on the Richter scale have been counted and plotted in figure 3. There is, however, a descending trend in their frequency but have not yet stopped fully. The micro-seismological recorder installed at Peer near Bhachau is still recording frequent tremors of magnitude 1.0 to 3.0 .

\section{Deformities, ruptures and fissures on the surface of the earth}

Information about various ground deformities collected from reliable individuals who visited the sites have been compiled and listed in table 1 .

\section{Future studies}

In view of the observations reported here, the following studies need to be undertaken. 


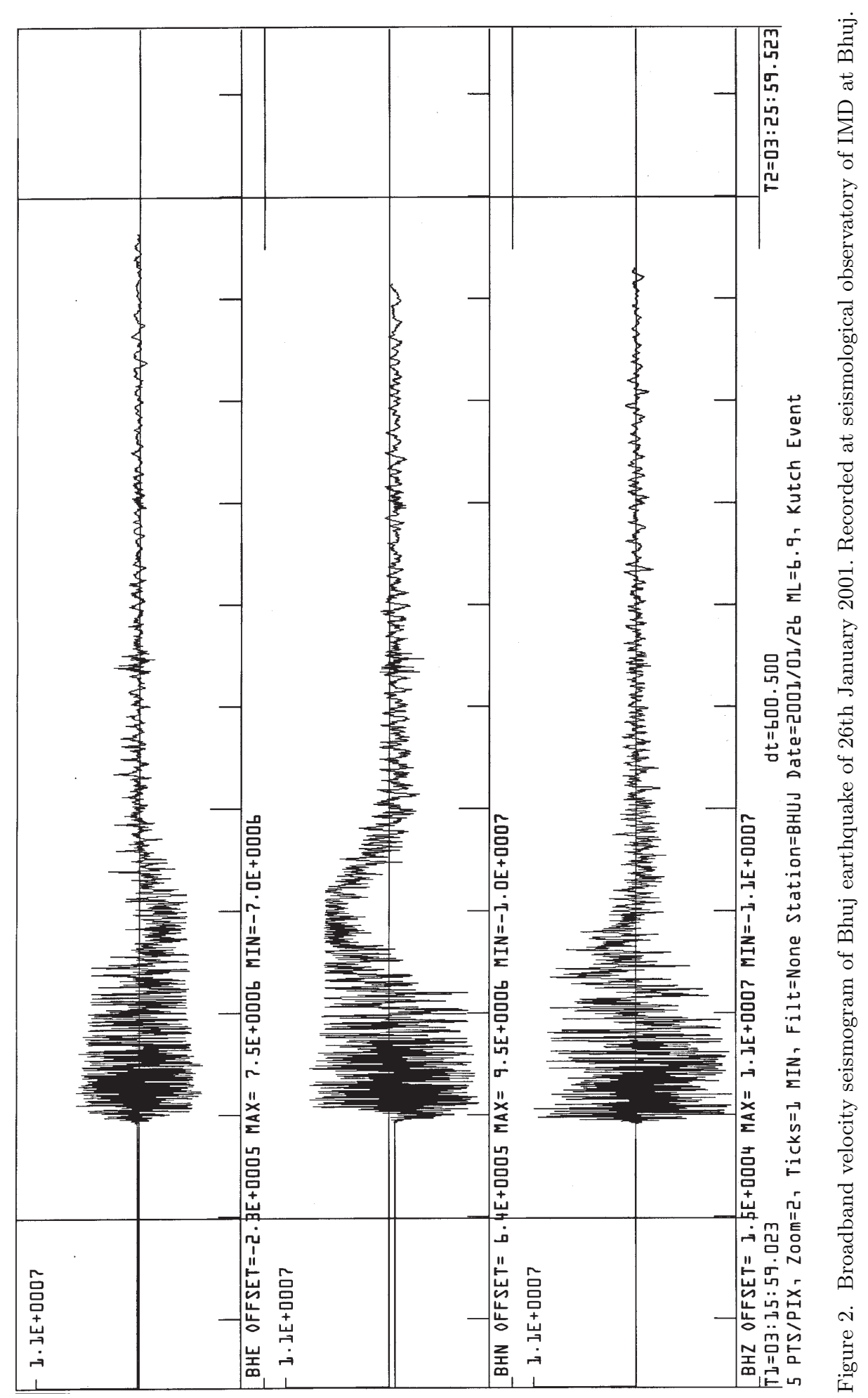




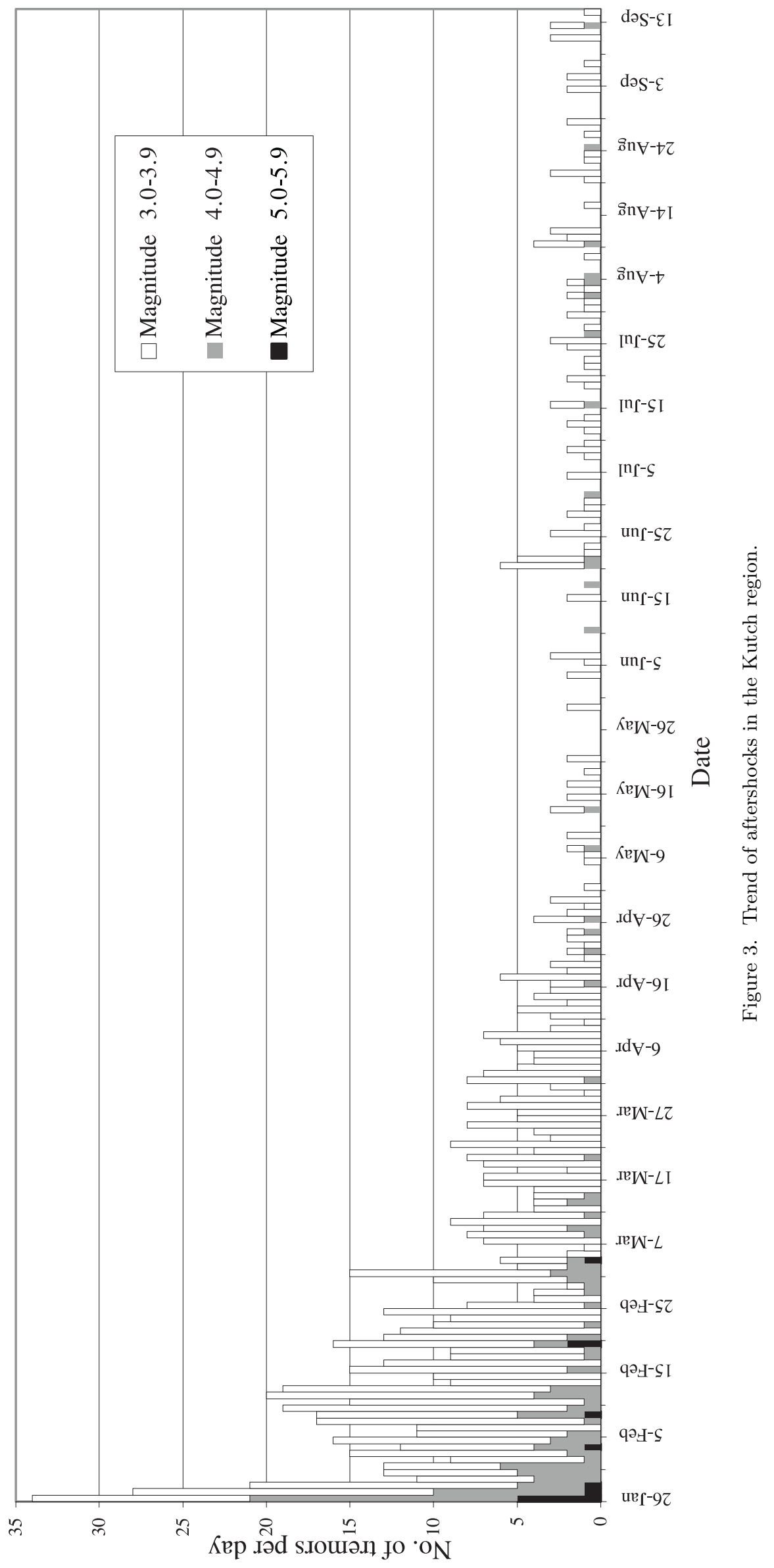


Table 1. List of ground deformities due to Bhuj earthquake.

\begin{tabular}{|c|c|c|}
\hline No. & Place & Description of ground deformation \\
\hline 1. & $\begin{array}{l}\text { Lodai village } 20 \mathrm{~km} \mathrm{NE} \text { of } \\
\text { Bhuj }\end{array}$ & $\begin{array}{l}\text { 1. Very prominent fissure up to one metre wide } \\
\text { extending } 1 \mathrm{~km} \text { in length. } \\
\text { 2. Several cracks on the crust of the earth and on } \\
\text { roads. }\end{array}$ \\
\hline 2 . & $\begin{array}{l}\text { Chobari village } 14 \mathrm{~km} \mathrm{~N} \text { of } \\
\text { Bhachau }\end{array}$ & $\begin{array}{l}\text { Upliftment of land up to one metre extending } \\
200 \mathrm{~m} \text { in length. }\end{array}$ \\
\hline 3. & $\begin{array}{l}\text { Various places in Rann of } \\
\text { Kutch. }\end{array}$ & $\begin{array}{l}\text { Numerous liquefaction vents through which sand, } \\
\text { silt and water sprouted during the earthquake up } \\
\text { to a height of } 2 \mathrm{~m} \text {. }\end{array}$ \\
\hline 4. & Bhachau & Railway track bent \\
\hline 5. & Navalakhi port & $\begin{array}{l}\text { 1. Slumping of railroad embankment and sagging } \\
\text { of railway track. } \\
\text { 2. Very prominent fissure. }\end{array}$ \\
\hline 6. & Anjar and Bhachau & $\begin{array}{l}\text { Several cracks on the crust of the earth and on } \\
\text { roads. }\end{array}$ \\
\hline
\end{tabular}

- There had been mild but frequent tremors in and around Bhavnagar during the six months period preceding the Bhuj earthquake which stopped after the tremor of December 24th, 2000. Is there any link between the Bhuj event and the tremors in Bhavnagar?

- A clear shift in the baseline of the trace is seen in the broadband velocity seismogram of the event (figure 2), which indicates an offset in the mean position of the sensor and hence that of the land evident. The sensor has to attain its mean position by virtue of its design in due course of time but what about the land. Was there a net displacement of earth crust?

- Why was the extent of damage more on the eastward side of the epicenter rather than on the westward side?

\section{Acknowledgement}

The author is grateful to Dr. S K Dikshit, Dy. Director General of Meteorology (surface instruments) for providing inspiration, encouragement and valuable guidance in the systematic and efficient description of the event. Thanks are also due to Sh. B N Gajjar and Sh. K C Modh for providing up-to-date information on the aftershocks.

\section{References}

Malik J N, Sohani P S, Karanth R V and Merh S S 1999 Modern and historic seismicity of Kuchchh peninsula, western India; J. Geol. Soc. India $\mathbf{5 4}$ pp 545-550 